\title{
Profile of IL-2, IL-4, IL-10, IFN- $\gamma$, TNF- $\alpha$ and KC-like cytokines in pregnant bitches
}

\author{
[Perfil de citocinas IL-2, IL-4, IL-10, IFN- $\gamma, T N F-\alpha$ e células KC-like \\ em cadelas gestantes] \\ M.A.R. Feliciano, A.S.L. Silva, R.M. Crivelaro, M.E.F. Oliveira, \\ L.N. Coutinho, W.R.R. Vicente \\ Faculdade de Ciências Agrárias e Veterinárias-Unesp/Jaboticabal - Jaboticabal, SP
}

\begin{abstract}
The aim of this study was to determine the profile of IL-2, IL-4, IL-10, IFN- $\gamma$, and TNF- $\alpha$ cytokines and KC-like cells (natural killer) in pregnant bitches, unpublished values for the species. A total of 27 females of the Shi Tzu, Pug, English Bulldog and French breeds, weighing 4-20kg and aged 4-6 years were used. Blood samples were collected from bitches during the anestrous and on the 2nd, 5th, 6th, 7th and 8th week of pregnancy. Serum levels of cytokines were measured by panel MILLIPLEX MAP (CCYTO90K, MILLIPORE, Billerica, Massachusetts, USA) validated for dogs. Twenty four females showed physiological pregnancy and three bitches showed pathological pregnancy. There was no difference between cytokine values during anestrous and gestational weeks of bitches $(\mathrm{P}>0.05)$. However, it was possible to verify the physiological behavior of serum levels during modulation of immune response in the gestational process of animals. In animals with gestational disorders, abnormal values for IL-2, IL-4 and INF-y were noted. It was concluded that serum levels of cytokines evaluated in pregnant bitches can help the better understanding of physiological and pathological gestational processes and correlated immunology in this species.
\end{abstract}

Keywords: dog, immunity, pregnancy

\section{RESUMO}

Objetivou-se por meio deste estudo determinar o perfil das citocinas IL-2, IL-4, IL-10, IFN- $\gamma$, TNF- $\alpha$ e células KC-like (natural killer) em cadelas gestantes, valores que são inéditos para a espécie. Foram utilizadas 27 fêmeas das raças Shi-tzu, Pug, Bulldog Inglês e Francês, pesando de 4 a $20 \mathrm{~kg}$ e com idade entre quatro e seis anos. Foram coletadas amostras sanguíneas das cadelas durante o anestro e na segunda, quinta, sexta, sétima e oitava semanas gestacionais. Os níveis séricos de citocinas foram dosados pelo painel MILLIPLEX MAP (CCYTO-90K, MILLIPORE, Billerica, Massachusetts, EUA) validado para cães. Vinte e quatro fêmeas apresentaram gestação fisiológica e três cadelas, gestação patológica. Não foi verificada diferença entre os valores das citocinas durante anestro e nas semanas gestacionais das cadelas $(P>0,05)$. Entretanto, foi possível verificar o comportamento fisiológico dos níveis séricos durante a modulação da resposta imune no processo gestacional dos animais. Verificaramse, nos animais com afecções gestacionais, valores alterados para IL-2, IL-4 e INF-y. Pôde-se concluir que os valores séricos das citocinas avaliadas, nas cadelas gestantes, podem auxiliar no maior conhecimento dos processos fisiológicos e patológicos da gestação, correlacionados à imunologia, nessa espécie.

Palavras-chave: cão, imunidade, gestação

Recebido em 31 de outubro de 2012

Aceito em 14 de dezembro de 2013

E-mail: marcusfeliciano@yahoo.com.br 


\section{INTRODUCTION}

The study of the immunological mechanisms of pregnancy in bitches can contribute to increase knowledge about immune tolerance, because the way the immune system is modulated during the gestational process allows us to understand the survival of the fetus. According to SzekeresBartho (2002), the immunological relationship between mother and fetus is a two-way communication that is observed by the antigen presented by the fetus and recognition of these by the maternal immune system. This interaction is an important step in maintaining pregnancy and failures in this process can result in spontaneous abortions in several species (Michelon et al., 2006; Mor et al., 2011).

Cytokines are soluble proteins synthesized by various cells of the immune system and which act as immune regulators. Among the major cytokines there are: those synthesized by type Th1 lymphocytes - interleukin-2 (IL2) and IL-12 and interferon-gamma (IFN- $\gamma$ ); those produced by type Th2 lymphocytes - IL-4, IL-5 and IL-13; and the type Th3 - IL-10. Furthermore, there is the category that includes TNF- $\alpha$ (tumor necrosis factor-alpha), IL-1 $\beta$, and IL- 6 cytokines, which have an anti-inflammatory function (Denney et al., 2011; Feliciano et al., 2012).

In recent years, some studies have been conducted in human medicine in order to better understand the role of cytokines in the gestational process of women, and there are no reports in veterinary of carrying out such research in bitches. Thus, the aim of this study was to determine the profile of IL-2, IL-4, IL-10, IFN- $\gamma$, and TNF- $\alpha$ cytokines and KC-like cells (natural killer) in pregnant bitches, unpublished values for the species.

\section{MATERIAL AND METHODS}

A total of 27 females of the Shi Tzu, Pug, English Bulldog and French breeds, weighing 4$20 \mathrm{~kg}$ and aged 4-6 years were used. The present study was performed under approval and the guidelines of the Committee for Ethics and Animal Use of the São Paulo State University, Unesp/Jaboticabal.

The animals were previously selected and considered healthy for the present study by physical and complementary exams (hemogram and biochemical profile) and obstetric examinations including specific reproductive tract inspection, abdominal palpation and imaging.

To monitor and determine the dogs' optimal mating period, vaginal cytology was carried out for four consecutive days. The material was collected using a swab, fixed with methanol and stained in glass slide by Giemsa. After this, the materials were performed in direct microscopy in increments of 25 and 100 diopters.

The estrus signs were also monitored and associated with direct microscopy findings. After the confirmation of probable date of higher fertility, the female in estrus and the male were put together and were separated after three days. While kept in touch, it was noticed that the female was receptive to the male mounts. The determination of pregnancy was carried out two weeks after mating, in analogy to that reported by Feliciano et al. (2007). The pregnancies were monitored by ultrasound exams on the 5th, 6th, 7 th and 8th weeks of pregnancy.

To evaluate the cytokine profile, blood samples were collected from bitches during the anoestrus period and on the 2nd, 5th, 6th, 7th and 8th weeks of pregnancy to evaluate the first third, middle and end of pregnancy of the bitches and follow the moments of ultrasound examinations performed. For the anoestrus samples from the animals, the collection was done two months after the parturition of the animals. After the collecting samples were arranged, the separation of serum was done and these were frozen and stored at $-80^{\circ} \mathrm{C}$.

Serum levels of IL-2, IL-4, IL-10, IFN- $\gamma$, TNF- $\alpha$ cytokines and $\mathrm{KC}$-like cells were assayed by cytokine panel MILLIPLEX MAP (CCYTO90K, Millipore, Billerica, Massachusetts, USA), validated for dogs. The samples and standards were incubated with microspheres coupled to a specific antibody. After washing, the biotinylated antibody was added for detection. There was then incubation with streptavidin-PE. Samples were read in the liquid array system - MILLIplex (Luminex 200, Luminex Corporation, St. Charles, Mo., USA). All procedure for analysis of the samples was conducted in the technician 
laboratory of GENESE LTDA., Sao Paulo - SP, Brazil.

The experimental design was completely randomized. Data were previously tested for normality of residuals and homogeneity of variance (F test). The PROC MEANS-SAS $®$ and GraphPad Prism 4 was used.

The real or transformed means were evaluated by analysis of variance and when there was significance, the statistical study of the means by paired means (t-test) and Tukey tests was conducted. The non-homogeneous means in the normality test were evaluated using the KruskalWallis and Dunn tests. A significance level of $5 \%$ was used for all tests.

\section{RESULTS}

Twenty four females showed physiological pregnancy without any complications during the pregnancy period. The mean pregnancy period in 25 bitches was 60 days, with a mean of four healthy pups per litter.

The serum profile of cytokines in bitches during the anoestrus and during pregnancy is shown in Table 1 and Figure 1.

It was observed that the mean values of cytokines evaluated showed no significant difference during the anoestrus and gestational weeks of bitches $(\mathrm{P}>0.05)$. However, it is possible to observe, in Figure 1, that in the anoetrus of bitches the serum levels of IL-2, IL4 , IL-10, IFN- $\gamma$ and TNF- $\alpha$ cytokines showed reduced values and high values for KC-like cells, when compared with the values obtained in pregnant bitches. For modulation of immune response in the gestational process of animals, there were high values for IL- 2 in the last three weeks of gestation, and IFN- $\gamma$ increased for the 2nd and 8th weeks of pregnancy compared to other results.

The gradual elevation of IL-4 from anoestrus until the 6th pregnancy week of bitches was also observed. After the peak, there was a decrease in serum levels, approaching the values observed in anoestrus. Serum levels of IL-10 during gestation remained constant having a small rise in the last two weeks of pregnancy.

In this study, three bitches showed pathological gestation: an animal with hydrops of maternal fetal membranes; another female with fetal anomalies and malformations, and one bitch presented single fetus syndrome; these last two diseases promoted stillbirth.

The bitch who had fetal malformations and stillbirths showed lower values of $\mathrm{IL}-2$ in anoestrus $(3.75 \mathrm{pg} / \mathrm{mL})$, and around the 6 th gestation week increased INF-y $(35.71 \mathrm{pg} / \mathrm{mL})$. The animal with hydrallantois also had lower values of IL-2 during anoestrus $(3.75 \mathrm{pg} / \mathrm{mL})$.

The female with the single fetus syndrome showed lower values of IL-2 $(3.75 \mathrm{pg} / \mathrm{ml})$ and increasing IFN-y (21.68 $\mathrm{pg} / \mathrm{mL})$ during anoestrus, increase in INF-y $(31.84 \mathrm{pg} / \mathrm{mL})$ on the 6th gestational week and increased IL-4 on the 2nd $(16.54 \mathrm{pg} / \mathrm{mL}), 5$ th $(21.96 \mathrm{pg} / \mathrm{mL})$ and 6th $(13.44 \mathrm{pg} / \mathrm{mL})$ gestational weeks.

Table 1. Mean values of the IL-2, IL-4, IL-10, IFN- $\gamma$, TNF- $\alpha$ cytokines and KC-like cells of bitches in anoestrus period and at $2 \mathrm{nd}, 5 \mathrm{th}, 6 \mathrm{th}, 7 \mathrm{th}$ and 8 th week of pregnancy

\begin{tabular}{lccccccc}
\hline $\begin{array}{c}\text { Cytokines } \\
(\mathrm{pg} / \mathrm{mL})\end{array}$ & Anoestrus & \multicolumn{5}{c}{ Pregnancy weeks } & $\mathrm{P}$ \\
\cline { 3 - 7 } & & $2^{\text {nd }}$ & $5^{\text {th }}$ & $6^{\text {th }}$ & $7^{\text {th }}$ & $8^{\text {th }}$ & $(5 \%)$ \\
\hline IL-2 & $220 \pm 192$ & $356 \pm 408$ & $288 \pm 295$ & $501 \pm 544$ & $537 \pm 794$ & $462 \pm 504$ & 0.51 \\
IL-4 & $1.04 \pm 0.86$ & $2.49 \pm 3.87$ & $3.07 \pm 3.34$ & $3.48 \pm 5.34$ & $2.17 \pm 3.13$ & $1.30 \pm 1.33$ & 0.21 \\
IL-10 & $3.10 \pm 1.76$ & $4.76 \pm 3.28$ & $4.72 \pm 3.63$ & $4.35 \pm 3.85$ & $5.90 \pm 4.98$ & $4.90 \pm 4.74$ & 0.86 \\
IFNy & $2.37 \pm 2.30$ & $7.39 \pm 7.96$ & $6.19 \pm 7.90$ & $6.93 \pm 8.67$ & $5.65 \pm 4.88$ & $8.67 \pm 10.15$ & 0.24 \\
KC-kiler & $842 \pm 372$ & $606 \pm 309$ & $658 \pm 334$ & $486 \pm 233$ & $608 \pm 306$ & $618 \pm 288$ & 0.33 \\
TNF- $\alpha$ & $1.39 \pm 1.29$ & $1.55 \pm 2.02$ & $2.25 \pm 1.80$ & $1.77 \pm 1.58$ & $2.09 \pm 2.19$ & $1.52 \pm 1.54$ & 0.69 \\
\hline
\end{tabular}

Paired t-test of means, Tukey, Kruskal-Wallis and Dunn tests for a significance level of 5\%. Significant for $\mathrm{P}<0.05$. 

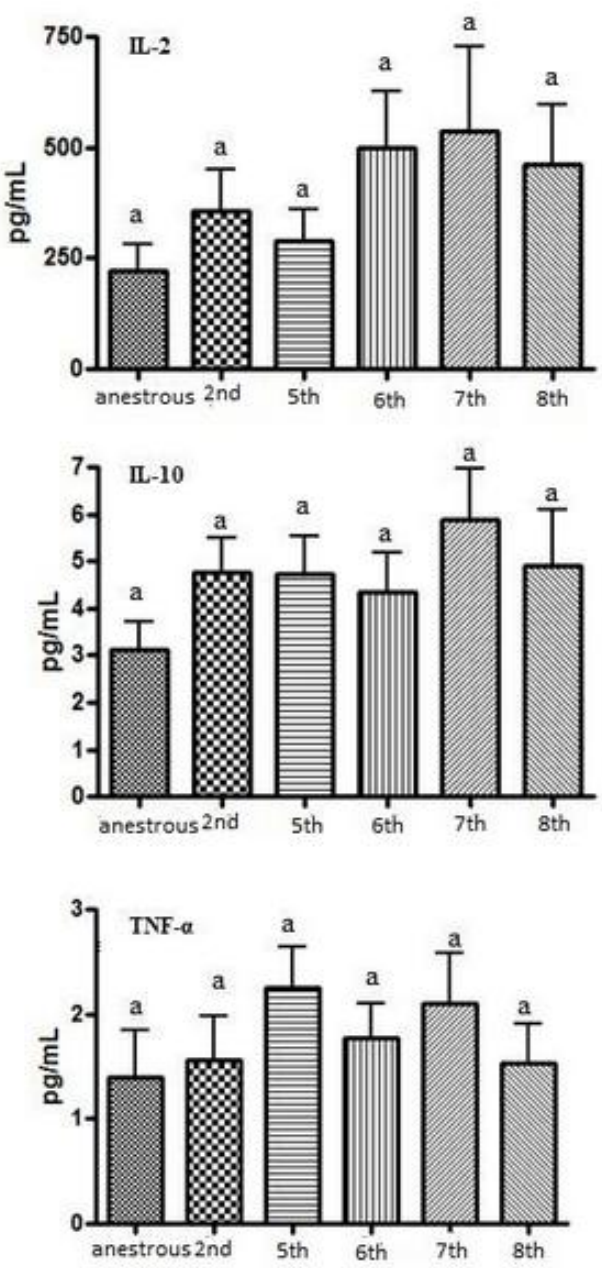
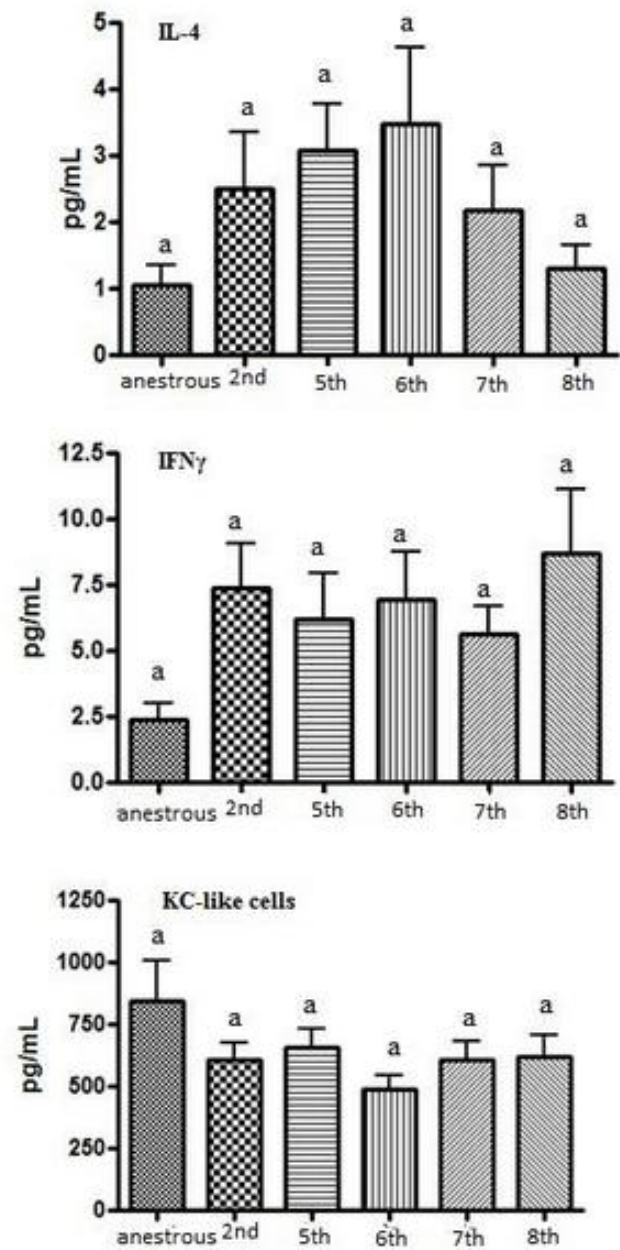

Figure 1. Graphical representation of the mean values for IL-2, IL-4, IL-10, IFNg, TNF- $\alpha$ cytokines and KC-like cells in anoestrus and pregnant bitches. Columns with different lowercase letters differ by the Tukey test at $5 \%$ significance.

\section{DISCUSSION}

Wegmann et al. (1993) presented the first theory to explain the involvement of cytokines in gestation. According to this proposition, the Th1 cytokines are deleterious, leading to an inflammatory response and placental necrosis, thus it can compromise fetal and/or placental development. Moreover, Th2 cytokines are beneficial for pregnancy, promoting proliferation and differentiation of the trophoblastic cells and placentation, in addition, have a protective role on the fetus' placental unit, inhibiting the production of Th1 cytokines. According to this theory, successful pregnancy is associated with preferential development of the Th2 profile. But with the advent of other researches that proposition is under review.

According to that, one of the main aspects is the inclusion of many other cytokines and mediators on the maternal-fetal interaction. Another important issue concerns the characterization of the immunological profile of the maternal-fetal relationship. Several studies showed that the pattern of cytokines is variable throughout pregnancy, and the observed effects depend on the concentration and the period (Daher et al. 1999). In this paper a non-well-defined pattern of response between cytokine relationships of Th1 and $\mathrm{Th} 2$ profiles in bitches is noticeable. 
Th2 cytokines (IL-4) can decrease Th1 responses (IL-2 and IFN- $\gamma$ ), creating an essential microenvironment for a good evolution of the pregnancy (Raghupaty, 1997; Michie 1998). However, Th1 cells have an essential role in the implantation and placental development. Thus, the balance is fundamental between Th1 and Th2, and this Th1/Th2 dichotomy can aid in the explanation about the environment of cytokines underlying a successful pregnancy (Mellor and Munn 2000).

Recent researches have shown that IFN- $\gamma$, and the paradigm of Th1 response, is a key element in the early stages of pregnancy, supporting the inflammatory reaction that enables the blastocyst nidation. Along other cytokines (IL-12, IL-15 and IL-18) produced by KC-like cells, IFN- $\gamma$ has an essential action on angiogenesis and the trophoblastic invasion process (Ashkar et al. 2003).

The balance of maternal immune response controlling the inflammatory mechanisms is dependent on IL-10. Regulatory features of IL-10 (pleomorphic cytokine) in the immunostimulatory and immunosuppressive activity might be associated to the regulation of the Th1-Th2 activities (Denney et al. 2011) and may reduce Th1 (IL-2 and IFN- $\gamma$ ).

In a normal pregnancy, the secretion of IL-10 assists the maintenance of a less proinflammatory environment, favoring a more regulated immune microenvironment that is opposite to the presence of a fetus. The IL-10 influences the activity of placental trophoblastic, has suppressive effect on $\mathrm{KC}$-like cells, on the autocrine production of $\mathrm{TNF}-\alpha$ and regulates fetal immunoprotection (Rein et al. 2003; Piccinni 2007).

In the beginning of the pregnancy, intense vascularization and cell proliferation helps the development of the embryo and the placentation, thus the presence of pro-inflammatory cytokines such as TNF- $\alpha$ and IFN- $\gamma$ is important at this early stage. The TNF- $\alpha$ modulates trophoblastic growth and the trophoblastic invasion of the spiral arterioles, although the overreaction can restrict the invasion and contribute to the pathophysiology of preeclampsia (Peracoli et al.
2007). Thus, it is essential to control this inflammatory response in the later stages of pregnancy and this is probably why levels of IL10 observed in this study remain high throughout pregnancy, linking to $\mathrm{TNF}-\alpha$ level to regulate them.

Pregnancy is a process which requires immunologic responses to allow growth and development of the fetus. Thus, changes in cytokine profiles may be involved in some aspects of gestation (Keelan and Mitchell, 2007). Following those changes, analyzing cytokines in dogs with gestational diseases, a low production of IL-2 during anestrus was observed. It is suggested that the decrease observed in these animals is associated with the presence of factors that inhibit the production of Th1 cytokines (IL-2) and these factors are important in the proliferation and differentiation of the trophoblastic cells and placentation and play a protective role on the fetal-placental unit as an attempt by the organism to maintain the pregnancy process. (Feliciano et al. 2012).

The high levels of INF-y and IL-4 observed in bitches with abnormalities or fetal malformation and single fetal syndrome may be correlated with the presence of the inflammatory process induced by the pathological condition present in pathological pregnancies in this study corroborating with Mor et al. (2011). This is supported by the findings of Daher and Mattar (2009) who observed that the main function of these cytokines is the pro inflammatory function, activation of macrophages and B-cells, antigen presentation for CD4 T lymphocytes, B-cell proliferation and induction of $\operatorname{IgE}$ immunoglobulin.

\section{CONCLUSION}

The serum cytokines values in pregnant dogs can help us better understand physiological and pathological processes of pregnancy.

\section{ACKNOWLEDGEMENTS}

The authors thank FAPESP for the scholarship and grant aid for post-doctoral research (processes 2010/16913-7 and 2011/06011-9). 


\section{REFERENCES}

ASHKAR, A.A.; BLACK, G.P.; WEI, Q. et al. Assessment of requirements for IL-15 and IFN regulatory factors in uterine $\mathrm{NK}$ cell differentiation and function during pregnancy. $J$. Immunol., v.171, p.2937-2944, 2003.

DAHER, S.; FONSECA, F.; RIBEIRO, O.G. et $a l$. Tumor necrosis factor during pregnacy and at the onset of labor and spntaneous abortion. EJOG, v.83, p.77-79, 1999.

DAHER, S; MATTAR, R. Gestação: um fenômeno imunológico? Rev. Bras. Alerg. Imunopatol., v.32, p.63-67, 2009.

DENNEY, J.M.; NELSON, E.L.; WADHWA, P.D. et al. Longitudinal modulation of immune system cytokine profile during pregnancy. Cytokine, v.53, p.170-177, 2011.

FELICIANO, M.A.R.; AQUINO, A.A.; COUTINHO, L.N. et al. Imunologia na gestação de cadelas: revisão de literatura. Rev. Bras. Reprod. Anim., v.36, p.158-162, 2012.

FELICIANO, M.A.R.; MUZZI, L.A.L.; LEITE, C.A.L. et al. Two-dimensional conventional, high resolution two-dimensional and threedimensional ultrasonography in the evaluation of pregnant bitch. Arq. Bras. Med. Vet. Zootec., v.59, p.1333-1337, 2007.

KEELAN, J.A.; MITCHELL, M.D. Placental cytokines and preeclampsia. Biosciense, v.12, p.2706-2727, 2007.

MELLOR, A.L.; MUNN, D.H. Immunology at the maternalfetal interface: lessons for $\mathrm{T}$ cell tolerance and suppression. Annual Rev. Immunologic, v.18, p.367-391, 2000.
MICHELON, T.; SILVEIRA, J.G.; GRAUDENZ, M. et al. Imunologia da gestação. AMRIGS, v.50, p.145-151, 2006.

MICHIE, C. Th1 and Th2 cytokines in pregnancy, from a fetal viewpoint. Immunol Today, v.19, p.333-334, 1998.

MOR, G.; CARDENAS, I.; ABRAHAMS, V. et al. Inflammation and pregnancy: the role of the immune system at the implantation site. Ann. N.Y. Acad. Sci., v.1221, p.80-87, 2011.

PERACOLI, J.C.; RUDGE, M.V.C.; PERACOLI, M.T.S. Tumor necrosis factor-alpha in gestation and puerperium of women with gestational hypertension and pre-eclampsia. Am. J. Reprod. Immunol., v.57, p.177-185, 2007.

PICCINNI, M.P. Role of T-cell cytokines in decidua and in cumulus oophorus during pregnancy. Gynecol. Obstet. Invest., v.64, p.144148, 2007.

RAGHUPATY, R. Th1-type immunity is compatible with sucessful pregnancy. Immunol. Today, v.18, p.478-82, 1997.

REIN, D.T.; BREIDENBACH, M.; HONSHEID, B. et al. Preeclamptic women are deficient of interleukin-10 as assessed by cytokine release of trophoblast cells in vitro. Cytokine, v.23, p.119125, 2003.

SZEKERES-BARTHO, J. Immunological relationship between the mother and the fetus. Int. Rev. Immunol., v.21, p.471-495, 2002.

WEGMANN, T.G.; LIN, H.; GUILBERT, L. et al. Bidirectional cytokine interactions in the maternal-fetal relationship: is successful pregnancy a Th2 phenomenon? Immunol. Today, v.14, p.353-356, 1993. 